\title{
Kemandirian Belajar Mahasiswa PGSD dalam Perkuliahan Secara Daring Pada Masa Pademi Covid-19
}

\author{
Dina Anika Marhayani ${ }^{1)}$ \\ 1) PGSD, STKIP Singkawang, Singkawang, Kalimantan Barat \\ E-mail:dinaanika89@gmail.com
}

\begin{abstract}
Fenomena yang banyak terjadi di kalangan mahasiswa adalah mahasiswa belum mampu mandiri dalam belajar hal ini dikarenakan oleh beberapa kebiasaan negatif, seperti belajar hanya saat menjelang ujian. Penelitian ini bertujuan untuk mengetahui gambaran kemandirian belajar mahasiswa PGSD dalam perkuliahan secara daring. Jenis penelitian ini aalah penelitian kuantitatif dengan rancangan deskriptif. Populasi pada penelitian ini adalah seluruh mahasiswa Prodi PGSD semester 5 STKIP Singkawang. Sampel diambil dengan menggunakan teknik snowball, sehingga di dapat sampel yakni mahasiswa berjumlah 85 orang. Instrumen yang digunakan dalam penelitian ini adalah angket kemandirian belajar pada mahasiswa yang dikembangkan oleh Sumarmo (2013). Hasil pengukuran terhadap kemandirian belajar menunjukkan bahwa responden memiliki kemandirian yang cenderung rendah dengan skor $51.95 \%$. Hasil ini menunjukkan bahwa mahasiwa belum cukup siap untuk belajar secara daring, penyebabnya adalah karena kebiasaan belajar, dan teknologi yang kurang mendukung. Pelaksanaan perkuliahan daring sebagai dampak dari pandemi Covid-19, ternyata belum cukup dapat dilaksanakan dengan baik, karena mahasiswa belum memiliki kemandirian dalam tingkat yang cukup tinggi
\end{abstract}

Keywords: Kemandirian belajar, perkuliahan daring, pademi covid 19

\section{PENDAHULUAN}

Pada masa sekarang ini, Indonesia dihadapkan dengan fenomena yang berkaitan dengan masalah kesehatan yaitu corona virus disease 2019 (Covid-19). Hal ini menjadi tantangan tersendiri bagi lembaga pendidikan terutama perguruan tinggi dengan adanya wabah corona virus disease 2019 (Covid-19). Upaya telah dilakukan oleh pemerintah pusat maupun daerah untuk menahan laju penularan, mulai dari pemberlakukan PSBB, peningkatan jumlah pemeriksaan PCR Covid-19, hingga pembuatan rumah sakit darurat Masyarakat juga sudah mulai sadar untuk melindungi diri dengan menggunakan masker dan membatasi keluar rumah dalam menekan penyebaran corona virus disease 2019 (Covid-19).

Kondisi penyebaran kasus corona virus disease 2019 (Covid-19) yang belum terjadi penururnan, maka Kementerian Pendidikan dan Kebudayaan Pemerintah telah melarang perguruan tinggi untuk melaksanakan perkuliahan tatap muka (konvensional) dan memerintahkan untuk menyelenggarakan perkuliahan atau perkuliahan secara daring (Surat Edaran Kemendikbud Dikti No. 1 tahun 2020). Terbitnya surat edaran dari Kemendikbud menjadi pedoman perguruan tinggi untuk mengubah metode perkuliahan tatap muka (face-to-face) menjadi e-learning. Segala kegiatan seperti kegiatan perkuliahan di Universitas harus dilakukan di rumah atau dilakukan secara daring untuk mencegah menyebarnya COVID-19 ini.

Perkuliahan secara daring menggunakan teknologi untuk pelaksanaan perkuliahannya [1]. Perkuliahan secara daring mengarah pada kegemaran belajar dan melakukan kajian pengembangan diri. Mahasiswa dalam perkuliahan daring adalah mereka yang membutuhkan materi perkuliahan tanpa meninggalkan rumah. Bahan ajar, diskusi, konsultasi, penugasan, latihan, ujian dilakukan secara daring tanpa harus tatap muka antara dosen dan mahasiswa. Perkuliahan secara daring memiliki banyak kelebihan dalam dunia pendidikan, khususnya dalam pendidikan jarak jauh. Kelebihan tersebut antara lain tersedianya fasilitas dimana dosen dan mahasiswa dapat berkomunikasi secara mudah melalui fasilitas internet secara regular atau kapan saja kegiatan berkomunikasi itu 
dilakukan dengan tanpa dibatasi oleh jarak, tempat dan waktu, dosen dan mahasiswa dapat menggunakan bahan ajar atau petunjuk belajar yang terstruktur dan terjadwal melalui internet, sehingga keduanya bisa saling menilai sampai berapa jauh bahan ajar dipelajari.

Fenomena yang banyak terjadi di kalangan mahasiswa adalah mahasiswa belum mampu mandiri dalam belajar hal ini dikarenakan oleh beberapa kebiasaan negatif, seperti belajar hanya saat menjelang ujian. Menurut Pratiwi \& Laksmiwati [2], adanya fenomena tersebut menimbulkan gangguan mental yang akan berlanjut ketika memasuki pendidikan lanjutan. Kemandirian belajar sendiri sangatlah diperlukan dalam sistem pendidikan tinggi, karena akan membantu individu untuk belajar dengan aktif. Kemandirian belajar menurut Muhtamadji [3] merupakan suatu sikap individu yang diperoleh secara kumulatif selama perkembangan, dimana individu akan terus belajar untuk bersikap mandiri dalam menghadapi berbagai situasi di lingkungan, sehingga individu pada akhirnya bertindak sendiri.

Permasalahan saat ini adalah proses perkuliahan yang terpaksa untuk dilakukan di rumah, sejak adanya pandemi. Perkuliahan daring menjadi alternatif agar perkuliahan tetap berlanjut. Perkuliahan secara daring memungkinkan seseorang dalam merencanakan perkuliahan sendiri, menentukan aktivitas belajarnya, dan kebebasan belajar untuk mencapai hasil belajar secara optimal. Individu tersebut dapat memiliki inisiatif dengan atau tanpa bantuan orang lain. Adanya fenomena pandemi COVID 19 peneliti tertarik untuk meneliti gambaran kemandirian belajar pada mahasiswa yang sedang melaksanakan perkuliahan daring. Kemandirian merupakan faktor yang sangat penting dalam menentukan keberhasilan mahasiswa ketika belajar. Menurut Hargis sebagaimana dikutip oleh Sumarmo [4], mengungkapkan bahwa individu yang memiliki kemandirian belajar tinggi cenderung belajar lebih baik, mampu memantau, mengevaluasi dan mengatur belajarnya secara efektif, menghemat waktu dalam menyelesaikan tugas dan memperoleh skor tinggi [4]. Kemandirian belajar merupakan aktivitas belajar yang dilakukan oleh individu dengan kebebasannya tanpa bergantung pada bantuan orang lain sebagai suatu peningkatan dalam hal pengetahuan, keterampilan, atau pengembangan prestasi, yang meliputi; menentukan dan mengelola sendiri bahan ajar, waktu, tempat, dan memanfaatkan berbagai sumber belajar yang diperlukan. Dengan kebebasan tersebut, individu memiliki kemampuan dalam mengelola cara belajar, memiliki rasa tanggung jawab yang tinggi, dan terampil memanfaatkan sumber belajar. Kemandirian belajar bukanlah belajar secara individual, melainkan proses belajar yang menuntut kemandirian seorang mahasiswa untuk belajar [5].

\section{METODE}

Jenis Penelitian ini adalah penelitian kuantitatif deskriptif. Populasi dalam penelitian ini adalah seluruh mahasiswa semester 5 PGSD STKIP Singkawang. Pemilihan sample menggunakan teknik snowball sampling, sehingga di dapat sampel yakni mahasiswa berjumlah 85 orang. Instrumen yang digunakan untuk mengumpulkan data adalah angket kemandirian belajar yang dikembangkan oleh Sumarmo
(2013). Angket pada penelitian ini terdiri dari 18 butir yang masuk ke dalam 9 indikator. Angket menggunakan skala likert dengan lima alternative jawaban, yaitu ( $5=$ sangat Setuju/SS $)$, ( 4 = Setuju/S $),(3=$ Netral/N), $(2=$ Tidak Setuju/ TS $)$, dan $(1$ = Sangat Tidak Setuju/STS). Jenis pernyataan dalam angket ini adalah pernyataan positif dan negatif.

Angket kemandirian belajar diuji dengan korelasi itemtotal correlation, dengan menggunakan rumus korelasi Product Moment dari Pearson. Uji hasil penghitungan menunjukkan bahwa 18 butir pernyataan dalam instrumen angket kemandirian belajar 18 indikator dikatakan valid. Sedangkan uji reliabilitas dengan Alpha Cronbach dengan skor 0,879 .

Tabel 1.

Kisi-kisi Instrumen Kemandirian Belajar

\begin{tabular}{|c|c|c|c|}
\hline No & Indikator & Nomor Item & Jumlah \\
\hline 1 & Inisiatif belajar & 1,2 & 2 \\
\hline 2 & Mendiagnosa & 3,4 & 2 \\
\hline & kebutuhan belajar & & \\
\hline 3 & $\begin{array}{l}\text { Menetapkan } \\
\text { target/tujuan }\end{array}$ & 5,6 & 2 \\
\hline 4 & $\begin{array}{l}\text { Memonitor, mengatur, } \\
\text { dan mengontrol belajar }\end{array}$ & 7,8 & 2 \\
\hline 5 & $\begin{array}{l}\text { Memandang kesulitan } \\
\text { belajar }\end{array}$ & 9,10 & 2 \\
\hline 6 & $\begin{array}{lr}\begin{array}{l}\text { Memanfaatkan } \\
\text { mencari }\end{array} & \text { dan } \\
\text { relevan } & \text { sumber }\end{array}$ & 11,12 & 2 \\
\hline 7 & $\begin{array}{lr}\text { Memilih } & \text { dan } \\
\text { menerapkan } & \text { strategi } \\
\text { belajar } & \end{array}$ & 13,14 & 2 \\
\hline 8 & $\begin{array}{l}\text { Mengevaluasi proses } \\
\text { dan hasil belajar }\end{array}$ & 15,16 & 2 \\
\hline 9 & Konsep diri & 17,18 & 2 \\
\hline
\end{tabular}

Penentuan presentase jawaban mahasiswa untuk masingmasing item pertanyaan atau pernyataan dalam angket, digunakan rumus menurut Lestari dan Yudhanegara [6] berikut:

$$
\mathrm{P}=\frac{\mathrm{f}}{\mathrm{n}} \times 100 \%
$$

$$
\begin{aligned}
& \text { Keterangan } \\
& \mathrm{P}=\text { Presentase jawaban } \\
& \mathrm{f}=\text { frekunensi jawaban } \\
& \mathrm{n}=\text { banyak responden }
\end{aligned}
$$

Presentase yang diperoleh pada masing-masing item pernyataan kelompok indikator. Kemudian ditafsirkan berdasarkan kategori berikut: 
Tabel 2.

Presentase dan Kategori Kemandirian Belajar

\begin{tabular}{cc}
\hline Presentase $(\%)$ & Kategori \\
\hline $85 \%-100 \%$ & Sangat Tinggi \\
$69 \%-84 \%$ & Tinggi \\
$53 \%-68 \%$ & Cukup Tinggi \\
$37 \%-52 \%$ & Rendah \\
$<36 \%$ & Sangat Rendah \\
\hline
\end{tabular}

\section{HASIL DAN PEMBAHASAN}

Data yang diperoleh melalui angket kemandirian, sebanyak 147 responden. Aspek yang diamati, antara lain: inisiatif belajar; mendiagnosa kebutuhan belajar; menetapkan target/ tujuan; memonitor, mengatur, dan mengontrol belajar; memandang kesulitan belajar; memanfaatkan dan mencari sumber relevan; memilih dan menerapkan strategi belajar; mengevaluasi proses dan hasil belajar; konsep diri. Berdasarkan setiap pernyataan dalam angket, keseluruhan responden menunjukkan kemandirian belajar daring adalah sebagai berikut:

Tabel 3.

Hasil angket Keseluruhan Kemandirian belajar

\begin{tabular}{|c|c|c|c|}
\hline No & Indikator & $\begin{array}{l}\text { Presentase per } \\
\text { indikator }\end{array}$ & Kategori \\
\hline 1 & Inisiatif belajar & $60.19 \%$ & $\begin{array}{l}\text { Cukup } \\
\text { Tinggi }\end{array}$ \\
\hline 2 & $\begin{array}{l}\text { Mendiagnosa } \\
\text { kebutuhan belajar }\end{array}$ & $56.13 \%$ & $\begin{array}{l}\text { Cukup } \\
\text { Tinggi }\end{array}$ \\
\hline 3 & $\begin{array}{l}\text { Menetapkan } \\
\text { target/tujuan }\end{array}$ & $60.17 \%$ & $\begin{array}{l}\text { Cukup } \\
\text { Tinggi }\end{array}$ \\
\hline 4 & $\begin{array}{l}\text { Memonitor, mengatur, } \\
\text { dan mengontrol belajar }\end{array}$ & $47.15 \%$ & Rendah \\
\hline 5 & $\begin{array}{l}\text { Memandang kesulitan } \\
\text { belajar }\end{array}$ & $55.13 \%$ & $\begin{array}{l}\text { Cukup } \\
\text { Tinggi }\end{array}$ \\
\hline 6 & $\begin{array}{l}\text { Memanfaatkan dan } \\
\text { mencari sumber relevan }\end{array}$ & $44.50 \%$ & Rendah \\
\hline 7 & $\begin{array}{lr}\text { Memilih } & \text { dan } \\
\text { menerapkan } & \text { strategi } \\
\text { belajar } & \end{array}$ & $51.16 \%$ & Rendah \\
\hline 8 & $\begin{array}{l}\text { Mengevaluasi proses } \\
\text { dan hasil belajar }\end{array}$ & $42.74 \%$ & Rendah \\
\hline 9 & Konsep diri & $50.40 \%$ & Rendah \\
\hline & Jumlah & $51.95 \%$ & Rendah \\
\hline
\end{tabular}

Berdasarkan tabel di atas terlihat bahwa skor rerata dari kemandirian belajar seluruh responden adalah $51.95 \%$, dapat disimpulkan bahwa tingkat kemandirian mahasiswa untuk belajar daring rendah. Apabila dirinci per indikator terlihat bahwa indikator 1, yaitu inisatif belajar memiliki skor $60.19 \%$. Hal ini menunjukkan bahwa mahasiswa memiliki insiatif belajar cukup tinggi. Mahasiswa dengan inisiatif belajar yang cukup tinggi akan belajar secara teratur. Selain itu mahasiswa juga cenderung aktif dalam proses perkuliahan dengan memberikan pendapat atau berkomentar ketika dosen menyampaikan materi di kelas secara online melalui Google Clasroom, Google Meet, atau Whatsapp. Indikator ke 2: mendiagnosa kebutuhan belajar, pada kategori cukup, dengan skor 56.13\% ini menunjukkan mahasiswa cukup tinggi mendiagnosa kebutuhan belajar secara daring. Mahasiswa selalu mempersiapkan diri sebelum perkuliahan berlangsung. Adapun yang dipersiapkan mahasiswa berupa buku, alat tulis, smartphone, dan kuota internet. Indikator ke 3 yitu menetapkan target/tujuan skor $60.17 \%$, artinya mahasiswa menetapkan tujuan cukup tinggi. Sebagian besar mahasiswa memiliki target berupa nilai yang harus dicapai. Dengan demikian, mahasiswa merasa bersemangat dalam perkuliahan, jika target belum tercapai, mahasiswa akan terus berusaha semaksimal mungkin agar bisa tercapai. Indikator ke 4 yaitu memonitor, mengatur, dan mengontrol belajar memiliki skor 47.15\%. Hal ini menunjukkan bahwa mahasiswa rendah memonitor, mengatur, dan mengontrol belajar. Indikator ke 5 yaitu memandang kesulitan belajar memiliki skor cukup tinggi dengan skor $55.13 \%$. Kesulitan merupakan hal wajar yang dihadapi oleh mahasiwa dalam proses perkuliahan. Mahasiswa berada pada kategori cukup tinggi dalam memandang kesulitan sebagai tantangan. Mahasiswa merasa senang dan tertantang ketika dosen memberikan tugas yang sulit serta berusaha mengerjakan tugas tersebut.

Indikator ke 6 memanfaatkan dan mencari sumber relevan juga memiliki skor $44.50 \%$, artinya mahasiswa memanfaatkan dan mencari sumber relevan pada kategori rendah. Sebagian besar mahasiwa sudah menggunakan sumber referensi lain untuk menunjang belajar, seperti Google, Youtube, dan buku-buku lain yang relevan namun belum optimal. Indikator ke -7 memilih dan menerapkan strategi belajar juga memiliki skor $51.16 \%$. Dalam proses perkuliahan secara daring, mahasiswa belum mampu menentukan sendiri strategi belajar yang digunakan. Berdasarkan angket kemandirian belajar mahasiswa diperoleh indikator memilih dan menerapkan strategi belajar berada pada kategori rendah, hanya sedikit mahasiswa belajar sendiri. Indikator ke-8 mengevaluasi proses dan hasil belajar memiliki skor $42.74 \%$. Mahasiswa berada pada kategori rendah untuk indikator mengevaluasi hasil proses belajar. Hampir seluruh mahasiswa merasa tidak senang dengan nilai yang diperoleh karena hasil belajarnya sendiri. Dan jika mendapat hasil yang kurang baik, mahasiswa cenderung lebih semangat untuk memperbaiki nilainya. Indikator ke-9 konsep diri memiliki skor $50.40 \%$. Konsep diri mahasiswa berada pada kategori rendah. Mahasiswa merasa belum siap untuk mengikuti perkuliahan secara daring.

Berdasarkan hasil diatas maka, secara keseluruhan mahasiswa memiliki tingkat kemandirian belajar yang rendah. Hal ini disebabkan karena perkuliahan secara daring menyebabkan mahasiswa mencari sumber referensi lain yang tidak diberikan oleh dosen seperti dari internet. Penyebabnya adalah tidak semua mahasiswa terbiasa belajar melalui daring [7]. Selain itu ditambah lagi mahasiswa masih banyak belum mahir menggunakan teknologi internet atau media sosial terutama di berbagai daerah, ini bisa menjadi salah satu alasan rendahnya peerkuliahan daring. Mahasiswa belum memiliki budaya belajar daring karena selama ini sistem belajar dilaksanakan melalui tatap muka. Di Indonesia penggunaan perkuliahan daring masih termasuk lamban 
berbeda dengan negara-negara maju diluar yang sudah menggunakan perkuliahan daring pada tahap yang lebih maju. Menurut Firman dan Rahman [8], daerah-daerah yang tidak memiliki konektivitas jaringan internet yang baik, perkuliahan online menunjukkan kecenderungan yang berbeda, wilayah yang tidak dijangkau jaringan internet mahasiswa harus menuju area-area tertentu.

Adanya Covid-19 memaksa mahasiswa untuk belajar dengan jarak jauh menggunakan teknologi, hal tersebut tentunya membawa perubahan dari perkuliahan tatap muka biasanya. Menurut Anhusadar [9] melalui perkuliahan tatap muka, mahasiswa bisa bertemu langsung dengan dosen, sehingga secara langsung memperoleh feedback dari hasil perkuliahan dibandingkan perkuliahan secara daring. Menurut Firman dan Rahman [8] belajar tanpa bimbingan langsung dari pendidik membuat peserta didik secara mandiri mencari informasi mengenai materi dan tugas-tugas yang diberikan kepada mereka. Ini akan membutuhkan keterlibatan peserta didik yang lebih besar.

\section{KESIMPULAN}

Mahasiwa belum cukup siap untuk belajar secara daring, penyebabnya adalah karena kebiasaan belajar, dan teknologi yang kurang mendukung. Pelaksanaan perkuliahan daring sebagai dampak dari pandemi Covid-19, ternyata belum cukup dapat dilaksanakan dengan baik, karena mahasiswa belum memiliki kemandirian dalam tingkat yang cukup tinggi. tingkat kemandirian mahasiswa untuk belajar daring cenderung rendah. Kebiasaan belajar secara tatap muka dimana mahasiswa memiliki kontak langsung membuat mereka belum dapat diganti secara daring. Peneliti selanjutkan diharapkan untuk mengkaji lebih banyak sumber maupun referensi yang terkait dengan kemandirian dalam perkuliahan daring agar hasil penelitiannya dapat lebih baik dan lebih lengkap.

\section{UCAPAN TERIMA KASIH}

Ucapan terimakasih kepada Bapak Andi Mursidi selaku Ketua STKIP Singkawang yang telah mendukung penelitian yang telah memberikan kesempatan untuk melakukan penelitian.

\section{DAFTAR PUSTAKA}

[1] T. Belawati, Perkuliahan Online, Banten: Universitas Terbuka, 2019.

[2] I. D. Pratiwi \& H. Laksmiwati, Kepercayaan diri dan kemandirian belajar pada siswa SMA Negeri X, Jurnal Psikologi Teori dan Terapan, Vol. 7, No.1, pp. 43-49, 2016.

[3] Muhtamadji, Pendidikan Keselamatan Konsep dan Penerapan, Jakarta : Depdiknas, 2002.

[4] Sumarmo. (2013). Kemandirian Belajar : Apa, Mengapa, dan Bagaimana Dikembangkan Pada Peserta Didik. [Online]. Available: http://math.sps.upi.edu/

[5] E. P. Astuti, "Kemandirian belajar matematika siswa SMP di kecamatan Prembun", Jurnal pendidikan surya edukasi, Vol.2, No.2, pp. $65-75,2016$.

[6] K.E. Lestari\& Yudhanegara, Penelitian Pendidikan Matematika, Bandung: Refika Aditama, 2015.

[7] A. Purwanto., R. Pramono, M. Asbari, dkk, "Studi Eksploratif Dampak Pandemi COVID-19 Terhadap Proses Perkuliahan Online di Sekolah Dasar”, Journal of Education, Psychology and Counseling. Vol. 2, No.1, pp.1-12, 2020.
[8] Firman, \& Rahman, "Perkuliahan Online di Tengah Pandemi Covid19”, Indonesian Journal of Educational Science (IJES), Vol.2, No.2, pp. 81-89, 2020 .

[9] L.O. Anhusadar, "Persepsi Mahasiswa PIAUD terhadap Kuliah Online di Masa Pandemi", KINDERGARTEN: Journal of Islamic Early Childhood Education, Vol. 3, No.1, pp. 44-58, 2020 